Mercator, Fortaleza, v. 16, e16021, 2017.

DOI: https://doi.org/10.4215/rm2017.e16021

ISSN: $1984-2201$

Copyright @ 2002, Universidade Federal do Ceará

\title{
PATENTS FROM FIRMS LOCATED IN THE BAIXADA FLUMINENSE, RIO DE JANEIRO
}

(a) Transport Engineering, Federal University of Rio de Janeiro (UFRJ). http://lattes.cnpq.br/5948639242737014

\section{(*) CORRESPONDING AUTHOR}

Address: Estrada de Adrianópolis, 1317 - Vila Nossa Sra. da Conceição, Nova Iguaçu - RJ, 26041-271, Brasil. Tel: (+55 21) 984730573

E-mail: joseavbm@yahoo.com.br

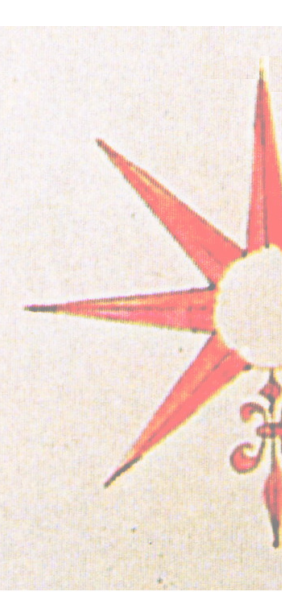

\section{ABSTRACT}

This article aims to map the geographical distribution of patents in the Baixada Fluminense region of Rio de Janeiro (Brazil), a proxy for the geographical distribution of innovation activities in the region. This research was based on a survey of the Brazilian patent base of the National Institute of Industrial Property (INPI). Taking into consideration the time required to perform a documental analysis during the available period, it was decided to perform a division of resident enterprises in the region in a time range of 13 years, from January 2001 to December 2013. The study shows a concentration of patents in two municipalities. On distribution by economic sectors there is a concentration of patents in three sectors and for the others the distribution of patents occurs on a regular basis. Regarding the type of registered patents, both types: utility model (MU) and invention patent (PI) are registered with a minimum quantitative difference. With the study, it was possible to note that the peripherical region of Baixada Fluminense is still behind and the competitive advantage based on patent registration is not a target of the resident companies.

Keywords: Baixada Fluminense; Patents; INPI.

\section{RESUMO/RESUMEN}

\section{PATENTES DAS EMPRESAS NA BAIXADA FLUMINENSE, RIO DE JANEIRO}

Este artigo tem como objetivo mapear a distribuição geográfica de patentes na região da Baixada Fluminense no Rio de Janeiro (Brasil), uma representação da distribuição geográfica das atividades de inovação na região. Esta pesquisa foi baseada em um levantamento da base de patentes brasileiras do Instituto Nacional de Propriedade Industrial (INPI). Tendo em conta o tempo necessário para realizar uma análise documental de todo o período disponível, foi decidido realizar uma divisão de empresas residentes na região num intervalo de tempo de 13 anos, de Janeiro de 2001 a Dezembro de 2013. O estudo mostra uma concentração de patentes em dois municípios. Na distribuição por setores econômicos há uma concentração de patentes em três setores e nos outros a distribuiccão de patentes ocorre em uma base regular. Quanto ao tipo de patentes registradas, ambos os tipos: modelo de utilidade (MU) e patente de invenção (PI) são registrados com uma diferença mínima em quantitativa. Com o estudo foi possível observar que a região periférica da Baixada Fluminense ainda está atrasada e a vantagem competitiva baseada no registro de patentes não é um alvo das empresas residentes.

Palavras-chave: Baixada Fluminense; Patentes; INPI.

\section{PATENTES DE LAS EMPRESAS EN LA BAJADA FLUMINENSE, RIO DE JANEIRO}

Este artículo tiene como objetivo mapear la distribución geográfica de patentes en la región de la Baixada Fluminense de Río de Janeiro (Brasil), un indicador de la distribución geográfica de las actividades de innovación en la región. Esta investigación se basó en un estudio de la base de patentes brasileñas del Instituto Nacional de la Propiedad Industrial (INPI). Teniendo en cuenta el tiempo necesario para realizar un análisis documental durante el período disponible, se decidió realizar una división de empresas residentes en la región en un intervalo de tiempo de 13 años, de enero de 2001 a diciembre de 2013. El estudio muestra una concentración de Patentes en dos municipios. En cuanto a la distribución por sectores económicos, hay una concentración de patentes en tres sectores y para los otros la distribución de patentes ocurre de manera regular. En cuanto al tipo de patentes registradas, ambos tipos: modelo de utilidad (MU) y patente de invención (PI) se registran con una diferencia cuantitativa mínima. Con el estudio se pudo constatar que la región periférica de la Baixada Fluminense sigue estando atrasada y que la ventaja competitiva basada en el registro de patentes no es un objetivo de las empresas residentes.

Palabras clave: Baixada Fluminense; Patentes; INPI. 


\section{INTRODUCTION}

Technological advances require a constant flow of new ideas and products to provide society with better living conditions and production efficiency. These technological advances are dependent fundamentally on new inventions and innovations. Within the framework of these changes, knowledge joins the traditional factors of production, building a "knowledge society". In view of the growing number of new technologies and products, caused by the highly demanding global market, knowledge management is necessary. To meet this current trend, the concept of innovation is present (SERRANO; GOBBO, 2014). Santos et al. (2016) point out that under R\&D investment, profit and value creation are superior in more innovative firms than in less innovative firms.

According to Nonaka (1995), in an economy marked by uncertainty, knowledge is the only safe and sustainable source of competitive advantage. Thus, the source of companies' wealth and economic value is no longer in the production of material goods, but in the creation and use of intangible assets. To maintain a competitive position and ensure its viability, companies have responded by investing in human resources, information technology, R\&D, outsourcing and advertising, and strengthening the emphasis on innovation as a major source of competitive advantage.

The relationship between territory and innovation contributes to geographers' debate on the theme of regional development. The right to protect innovations in the development of a process or product and to commercially exploit a new process or product is ensured by the patent, which is recognized as a protective tool and an important source of technological information.

According to Canongia, et al. (2002), given its informative content, a patent document permits the identification of relevant technologies, partners, niche markets for performance, incremental innovations and the movements of the competition, such as investments, process management, product management, new lines of research and development (R\&D), mergers and acquisitions, among others.

The patent is an industrial property protection mechanism and an important indicator of the intermediate results of innovative activity. For this reason, the number of records and patent applications in the country, made available by the National Institute of Intellectual Property, is one of the components of the Brazil Innovation Index. In a recent study Sabino (2007) demonstrated that the protection of intellectual property through patents stimulates the country's economic development and technological innovations that generate wealth and general well-being. According to Suzigan et al. (2006), the regional distribution of scientific activities, technology and innovation reflects the regional distribution of knowledge substantiating technical training, science and technology. These, in turn, encourage the location of productive activities and the formation of agglomerations of companies that in many cases make up clusters or geographically restricted innovative production systems.

Urban centers are perceived as places where variety and scale occur together, being understood as "centripetal" forces acting as factors that encourage the positioning in cities (MCCANN, 2014). Due to urban evolution, relations of centrality tend not to remain constant, especially when peripheral areas emerge and orbit around a main center (MELLO et al., 2016). In the field of innovation economics, interest in regional analysis arises from the development of the concept of localized knowledge spillovers (AUDRETSCH; ALDRIDGE, 2009). The gap that this study deals with is based on a study by Rodriguez and Gonçalves (2015) that reinforces the idea that spill overs and regional innovation are geographically defined. There are two main approaches in spatial analysis: the temporal focus of innovative activity in a country or region and understanding the spatial distribution of innovative activity, seeking to understand why certain urban areas have greater inventiveness than others.

Patents can impact the overall rate of innovation and economic development of a country (SOUSA, 2014). Within this context, this article aims to map the geographical distribution of pa- 
tents in the Baixada Fluminense region of Rio de Janeiro, a proxy for the geographical distribution of innovation activities in the region.

Marked historically by a constantly changing area, the Baixada Fluminense region (inserted in the metropolitan region of Rio de Janeiro) has undergone various social and spatial restructurings, in terms of its territorial and administrative dimensions (via municipal emancipations) and also changes in its socioeconomic profile (a basically rural area, which currently has production poles and services strongly connected to the center of Rio de Janeiro). Unlike studies about central areas, this study is important because it evidences that companies located in the Baixada Fluminense, despite being installed in one of the most innovative states in Brazil, are not very innovative themselves. This analysis reaffirms the asymmetries between the periphery and central areas.

It is believed that different measurements of concentration can be combined to reveal the level of inequality, rank, and spatial pooling of of different technological innovations in the Brazilian system, analyzed by regions of influence. Raeder (2016) says that the sub-discipline of of Innovation Geography does not receive as much attention from geographers, but whereas there are numerous studies that value the technological dimension fof territorial impacts. Therefore, There is a need for studies that make innovation a central dimension in geographical analyses are necessary.

The quantitative analysis of patents is a useful tool for obtaining data on industry, both to evaluate general trends, andand the strategic positioning of individual industries. Through this analysis explicit structural characteristics of the innovation system of the studied region's can be made can be made, such as its concentration. The availability of such statistical information on the distribution of innovation can add an important element toto the evaluation of the the dynamic, contributing to the development of specific public policies for the region.

\section{THE INNOVATION AND PATENT SYSTEM IN BRAZIL}

\section{THE SCOPE OF INNOVATION}

The work of Joseph Schumpeter in the early twentieth century had a considerable impact onon technological change and economic development. According to the author, investments in new combinations of products and production processes of a company have a direct impact on its financial performance, so the modern capitalist entrepreneur should play the role of both both economic and technological leader. Entrepreneurial behavior, with the introduction and expansion of technological and organizational innovations in enterprises is a key factor for the changes in the economic sphere and its development over time (SCHUMPETER, 1982).

According to Barbieri and Alvares (2004), the verb innovate comes from the Latin (innovare) and means to to renew or introduce changes of any kind. Innovation is a variation and means renewed or made new. The concept of innovation is quite varied, depending mainly on its its application. The idea of innovation is conceived as a creation or renewal of something that already exists, using studies, observations and persistence in the pursuit of practical and simple solutions, so they can be easily understood and accepted by consumers.

Innovation, in its most general sense, can be defined as something new to the organization. Thus, the scope of the term requires a more specific definition. Innovation is often used to describe an object that can be a microcomputer or a new car model. While referring to something "concrete", theorists in this field agree that innovation can take other forms of resolution. For example, Costa and Rodrigues (2015) show that technological innovation can enable an optimization of energy, especially in terms of renewable energy, especially biomass, thus enabling the energy-production base model of Sustainable Development. 
When product and process innovations are accompanied by the insertion of new technologies - that is, scientific and empirical knowledge employed in any industry - these are refered to as technological innovations (ANDREASSI, 2007).

\section{INTELLECTUAL PROPERTY}

Human intelligence, creativity and ingenuity, when applied in intellectual work, often generate creations that can be both tangible and intangible. Examples of the former are forms such as paintings, sculptures and landscaping, to be enjoyed by admirers. In the latter, examples include music and technology, which despite being intangible are intended for the production of tangible goods.

Traditionally, material ownership referes to tangible assets such as a house, land, a farm, or any other object. More than that, property is spoken of as an exclusive and absolute right (SALINAS, 2007). Macedo (2010) argues that when intellectual work is directly related with economic production, protection is afforded by the Industrial Property, which protects inventions in the sphere of production - the patent invention and utility model - and all other creative forms to facilitate and expedite the commercialization of goods-trademarks, industrial design, etc. According to Lazzari et al. (2014), patents are classed by: invention patents, the utility model and the certificate of addition of invention. The invention patents (IP) consist of the products or processes that characterize the invention, novelty and industrial application. The utility model (UM) basically concerns the practical use of an object in a new form, involving an inventive act and is susceptible to industrial application. Finally, the certificate of addition of invention comprises improvements to the object of the invention.

The Industrial Property regulates the protection of the temporary rights granted to authors of intellectual creations of an innovative, utilitarian, industrial or commercial nature, such as inventions, utility models, trademarks, industrial designs, new plant varieties and crackdowns on false geographical indications and unfair competition.

Once the innovativeness and applicability of an invention has been proven, it receives a patent, which according to Teixeira (1997), is the right to commercially exploit an invention for a certain, constitutive time. It is a type of contract where direct exclusivity is exchanged for public disclosure regarding the invention. For him, the patent enables scientific research, protecting the results obtained through investments.

For Sáenz and Garcia (2002), a patent is an exclusive right granted to the author of an invention for its operation; the recognition of the patent prevents the invention being used in any form by a third person, for a certain period of time. Wandscheer (2004) considers a patent right granted to the author of an invention as a privilege, ensuring exclusive commercial use and restricting use by unauthorized third parties. The patent's aim is to protect intellectual property rights, which are the intangible value of goods created by human intelligence.

\section{THE PATENT SYSTEM IN BRAZIL}

According to the INPI (2011), the Brazilian patent system includes creations in the industrial field, through forms of protection such as patents, the utility model and the certificate of addition of invention, and records of industrial design. Accordingly, (MANUAL INDUSTRIAL PROPERTY - Abimaq / IPD-Maq, 2008), a patent is the invention itself, resulting from man's constructive capacity, that represents a solution to a specific technical problem, within a specific technological field and that can be manufactured or used industrially.

The certificate of addition to invention protects improvements or developments of a technical solution that do not constitute a new invention. That is, an improvement or development applied to a given invention for which a patent application or invention patent has already been granted. Protection only applies to the applicant or proprietor of the original invention to which the certificate relates (art. 76 of Law No. 9279/96). 
A certificate of addition is an accessory to the main patent, it has the same expiry date and accompanies it for all legal purposes (Art. 77 of Law No. 9279/96). According to Article 9, Industrial Property Law, a utility model is considered "the object of practical use, or part thereof, susceptible to industrial application, which presents a new form or arrangement and involves an inventive act that results in a functional improvement in its use or manufacture. "

Among patents there is an important distinction: residents versus non-residents. According to the World Intellectual Property Organization (WIPO) and the National Patent Offices, residents are applicants and patent holders who live (for individuals) or operate (in the case of firms and institutions) in the country granting the patent. This observation is important because it makes clear that patents granted by a National Patent Office to subsidiaries of transnational companies are counted as resident's patent.

The patent for products or processes that meet the requirements of an inventive step, innovativeness and industrial application is valid for 20 years from the date of filing. The utility model of an object of practical use, or part thereof, susceptible to industrial application, presents a new form or arrangement and involves an inventive act that results in functional improvement in its use or manufacture is valid for 15 years from the date of filing.

Although during this term the patent can accrue the payment of royalties, and after this period may be used free of charge, the information contained in it, available in the patent document, can be used for various purposes, without damaging the right to property, even during the term of patent protection (CUNHA, 2001). Régibeau and Rockett (2003) studied the relationship between the time of a patent's evaluation and its economic importance. Analyzing this relationship's importance from the standpoint of the invention, the social benefit of the invention decreases as the time assessed increases.

Table 1 - Patent Deposit by origin of the applicant

\begin{tabular}{l|c|c|r|r|r}
\hline Year & $\begin{array}{c}\text { Resident } \\
\text { NPCT }\end{array}$ & $\begin{array}{c}\text { Not Residents } \\
\text { NPCT }\end{array}$ & $\begin{array}{c}\text { Not Residents } \\
\text { PCT }\end{array}$ & Others & Total \\
\hline 2000 & 6.416 & 3.715 & 10.466 & 257 & 20.854 \\
\hline 2001 & 6.938 & 3.376 & 11.118 & 123 & 21.555 \\
\hline 2002 & 7.035 & 2.522 & 10.734 & 43 & 20.334 \\
\hline 2003 & 7.547 & 2.238 & 10.367 & 24 & 20.176 \\
\hline 2004 & 7.682 & 2.429 & 10.296 & 24 & 20.431 \\
\hline 2005 & 7.322 & 2.493 & 11.977 & 60 & 21.852 \\
\hline 2006 & 7.171 & 2.309 & 13.628 & 44 & 23.152 \\
\hline 2007 & 7.290 & 2.276 & 15.220 & 54 & 24.840 \\
\hline 2008 & 7.681 & 2.115 & 16.790 & 55 & 26.641 \\
\hline 2009 & 7.640 & 2.064 & 16.080 & 101 & 25.885 \\
\hline 2010 & 7.182 & 2.183 & 18.642 & 92 & 28.099 \\
\hline 2011 & 7.727 & 2.780 & 21.275 & 99 & 31.881 \\
\hline 2012 & 7.725 & 3.149 & 22.575 & 120 & 33.569 \\
\hline 2013 & 7.817 & 3.603 & 22.472 & 158 & 34.050 \\
\hline
\end{tabular}

Adapted from www.mct.gov.br/upd_blob/0237/237024.pdf

$\mathrm{NPCT}=$ Patent Invention (PI) + Utility Model (UM) + Addition Certificate (CA). $\mathrm{PCT}=$ Patent Cooperation Treaty

A patent requires the submission of an application to the INPI with specifications, claims, drawings, and proof of payment of the filing fee (BARBOSA, 2010). Brazil opted for the most popular protection system in the world, recognizing the right on a first-come basis to proceed with the filing of the patent application. The patent has the exclusive right that guarantees the right of commercial exploitation of the invention. Without the owner's consent, third parties are excluded from acts of commercial exploitation, such as manufacturing, marketing, import, use, sale, etc. 
(Art. 42 of Law No. 9279/96). Table 1 shows the patents registered with the INPI between 2000 to 2012; the data show a decline in the number of patents registered from 2000.

Patents of non-residents have historically dominated the records in Brazil, this prevalence of non-resident patent depositors is not a Brazilian peculiarity, it is also common among developing countries and its importance has become even greater since the introduction of the Current Industrial Property Law in 1996.

A patent has a territorial effect, that is, it is valid only in the country where it was registered. There is not, at present, a form of patent to protect inventions worldwide. Thus, to obtain the right to prevent competitors from exploiting an invention abroad, patent applications must be made in all the countries or regions of interest. With the increasingly globalized economy, patents are used more and more to ensure markets for technology holders.

\section{METHODOLOGIES}

\section{FIELD OF STUDY}

The Baixada Fluminense is a peripheral region of Rio de Janeiro State, its current population is estimated at about 3.7 million inhabitants (IBGE, 2010), distributed in 13 cities: Belford Roxo, Duque de Caxias, Guapimirim, Itaguaí, Japeri, Mage, Mesquita, Nilópolis, Nova Iguaçu, Paracambi, Queimados, São João de Meriti and Seropédica. Baixada Fluminense is recognized as a peripheral area due to its historically negative charge. It is associated as a space of absences: of law, sanitation, security, employment.

Despite the history that gave birth to the region, Baixada Fluminense emerges as an important region in the industrial development of the state of Rio de Janeiro, seeking a new role, "a new identity" of guided growth supported by economic development. The two largest municipalities of Baixada Fluminense in terms of production (gross domestic product) and resident population are Duque de Caxias and Nova Iguaçu (IBGE, 2016), which explains the concentration of business and a hypothetical concentration of patents in them.

This study aimed to obtain information about patents registered at INPI by the industries of the Baixada Fluminense and how these contribute to the aggregate numbers on innovation. For its methodological development this research follows the exploratory-descriptive and quantitative approaches which will be used as statistical techniques together with the analysis of phenomena and the attribution of meaning to the data.

\section{INDICATORS FOR PATENT ANALYSIS}

Archibugi (1996) comments that is not easy to identify innovative activities occurring in industries. Trade secrets often hinder this process. A wide range of technological activities can be identified by patents. In the words of Archibugi (1996), "a patent is a fascinating indicator leading the researcher in the process of invention and innovation. They can assist in gathering information about the intangible phenomenon that is knowledge".

One of the indicators most commonly used in the analysis of production technology is constructed from the patents granted by statistics or office industrial or intellectual property. Fornari et al. (2015) show that the analysis of patent applications allows the measurement of the results of innovation activities of firms that provide the acquisition and development of the encoded knowledge base and the expansion of expertise in various scientific fields.

Godin (2002) argues that the first indicator to appear in the history of the measurement of science and technology, even before the research and development of statistics, was the patent. This analysis was based on the work of Schmookler, as well as other economists and sociologists who 
used patent statistics to develop studies of science and technology in the 1930s and 1940s. Abraham and Moitra (2000) argued that the analysis of patent documents has been considered an important tool for access to multiple aspects of technological change. Studies use patent statistics as a method to understand the relationship between technological development and economic growth, or even for access to research and innovation processes in a national and international context.

Griliches (1990) points out that patent statistics represent an important indicator in the economic analysis of inventive activity. A patent is really a minimum quantum of invention that is displayed by the official body responsible for granting industrial rights. For Sousa (2014) patent applications made by companies, universities and governments permit experts to measure the degree of innovation in an economy. According to Suzigan et al. (2006) the common basis for the various approaches is the perception that geographical proximity facilitates the transmission of new knowledge characterized as complex, tacit and specific in nature of certain activities and production and innovation systems

So, making a city competitive in terms of innovation can transform its reality, but it is not easy, there are a lot of difficulties. Ceretta and Froemming (2015) explain that managing cities proves to be even more comprehensive and challenging because of the many variables and internal and external factors that impact directly on decision-making involving the choice of actions to perform.

\section{RESEARCH DESCRIPTION}

According to the objectives proposed for this work, the research will create analytical subsidies that can be used in the resolution of these problems or the formulation of new public policies relevant to the topic under discussion. To delimitate the universe to be studied, a survey of the main patent databases was carried out and a pretest was conducted using the previously listed search terms, such as the Register of Corporate Taxpayers with the Federal Revenue Service (CNPJ) and company name, in order to verify the facility, the search engine database and its interface.

This research surveyed patent information in the INPI national patent database that originated the research question motivating the investigation. According to Maricato et al. (2010) patent documents have their own peculiarities and features and there are extensive electronic databases. The aforementioned document has been widely used to construct windows and technological efforts to perform approaches regarding the innovative activity of firms, countries, regions, and sectors.

This is a bibliographic research and documentation was obtained mainly through electronic searches. Next, material was selected about intellectual property, patents, research and development, and other areas, seeking to evaluate the methodological procedures adopted by the researchers. To support the issues raised a review of books and articles dealing exclusively with issues related to the research methodology.

The INPI patent records from 1992 to 2013 were collected. The time period considered makes a documental analysis of the period possible. The temporal and regional dimensions were established based on the work of Audretsch and Aldridge (2009) and Rodriguez and Gonçalves (2015).

To identify the companies that were the object of this study a survey was carried out to isolate the name and the National Classification of Economic Activities (CNAE) of small, medium and large industries in the Baixada Fluminense.

From the survey of company data, we filtered those industries which have headquarters in the study area, excluding those based in other states or countries. Resident firm means a Brazilian company that has its headquarters in the Baixada. Non-resident means a local representation of a transnational that is headquartered outside Brazil. The initial survey indicated 174 industries installed in the Baixada Fluminense that were classified as small, medium and large. Of the 174 industries surveyed, 15 are branches of industries in other states of the country, 3 were branches of industries in the municipality of Rio de Janeiro, and 3 were multinational industries based in other countries. Once filtered, 153 industries were identified to be searched for in the INPI. 
Patent registration information from resident industries in the Baixada Fluminense was extracted from the electronic INPI page, which allows the patent search by case number, and / or title, abstract, applicant name, inventor's name and the Individual Taxpayer's Registration Number (CPF) / CNPJ of the depositor. The search using each selected company's CNPJ is dispalyed in Figure 1, showing the company's processes, the filing date and the title of the patent. After this phase, the patent documents filed by the company were evaluated taking into account criteria such as the patent certificate and date of patenting. When choosing a patent for analysis the following data are provided by the platform: case number, filing date, rating, title, abstract, applicant's name, inventor's name, attorney's name, and general payment information.

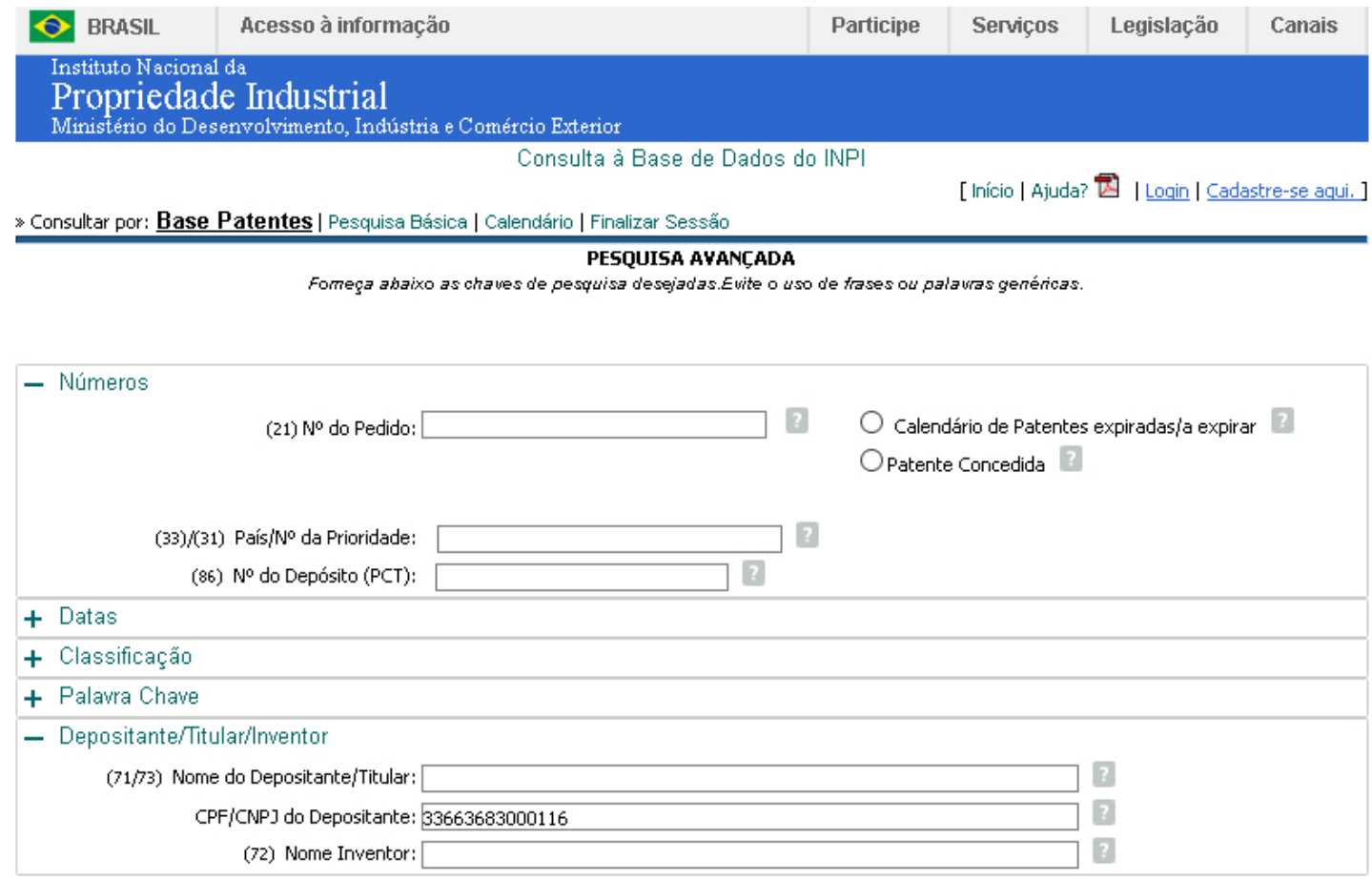

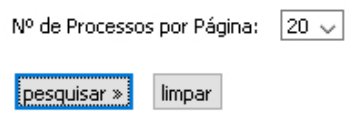

Figure 1 - Screen search for patent applications on the INPI site

The following data were collected: title, date of filing, the company's CNPJ, company name and case number. The purpose of the survey was to extract as much information from patent documents as possible, to comply with the proposal of this study. Therefore, patent documents were accessed and analyzed individually in the period defined for each company.

After collecting the data, they were organized according to the type of patent, within the type of business segment.

\section{RESULTS}

For the study, 153 industries, $88 \%$ of the total, were the subject of research (see Figure 2). This selection occurred because for the other companies there was no way to distinguish which subsidiary developed the innovation that gave rise to the patent registered. In many cases it is the headquarters of these companies that applies for the registration. 


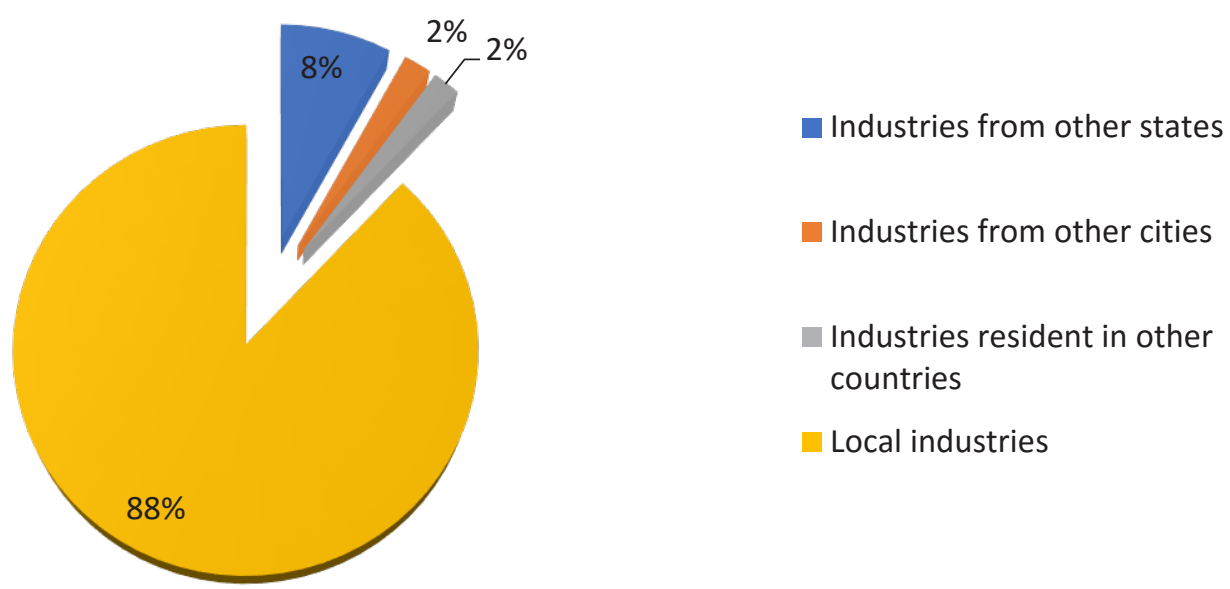

Figure 2 - Graph 1, Industries in Baixada Fluminense.

Figure 3 shows the distribution of the companies studied in the Baixada Fluminense. The city of Duque de Caxias concentrates most of the industries studied; $48 \%$ of resident companies. $20 \%$ are residents in Nova Iguaçu and in other cities the percentage varies between $0 \%$ and $7 \%$ of the quantitative study of industries.

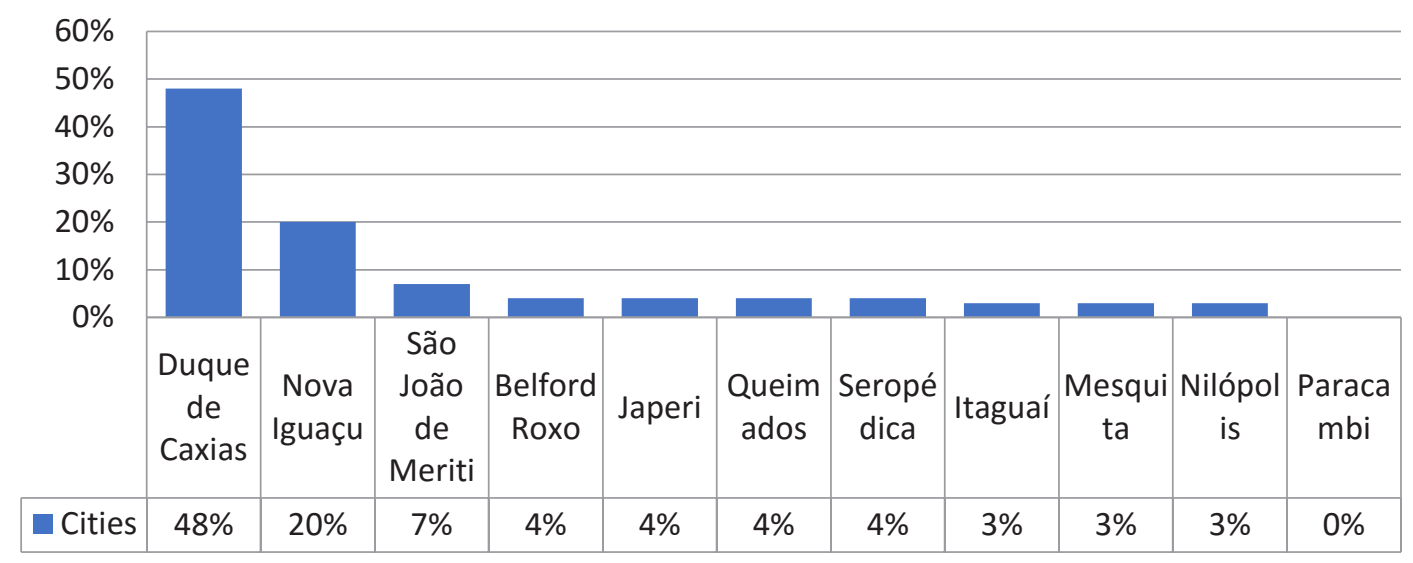

Distribution of industries by municipalities.

Regarding the distribution by sectors, using the classification established by the National Classification of Economic Activities (CNAE), which is the national standardization instrument of economic activity codes, from the total number of industries studied, $29 \%$ work in the petroleum sector. The other two major sectors are the manufacturing of soaps, detergents and cleaning materials with $10 \%$ of the industries and the manufacture of various chemical products and processed food account for $7 \%$ of the industries.

In the period under analysis (2001-2013), it was observed that 14 of the 153 companies in the Baixada Fluminense region registered patents in the INPI database, only $9 \%$ of companies are holding patents filed in the period and 139 companies do not have any kind of patenting. The analysis of patent applications found that 37 patents have been filed by the companies studied. Table 2 shows the amount of patents by cities located in the study area. The results show a geographical concentration of patent applications in two cities. The companies in Nova Iguaçu account for $54 \%$ of the patenst filed, followed by 38\% from the city of Duque de Caxias and $8 \%$ from São João de Meriti. It is noteworthy that companies from other municipalities had no patent applications in the period.

In the patent records of industries in Nova Iguaçu, the invention patent (IP) mode predominates, with $60 \%$ of patents; $40 \%$ are the utility model type. In the municipality of Duque de Caxias, $57 \%$ of patents are of the utility model type. 
The results of companies headquartered in the Baixada, the target area of the study, show little patent development. The evolution of patent applications is given in Table 2, which show a growth in patents registered between 2004 and 2005. This growth may be related to the enactment of the Brazilian Innovation Law in 2005. However, the volume of patent deposits in this region in the following years fell, reaching zero in the years 2012 and 2013.

Table 2 - Types of patents registered by cities.

\begin{tabular}{|c|c|c|c|c|c|c|c|c|c|c|c|c|c|c|c|c|c|c|c|c|c|c|c|}
\hline \multirow{2}{*}{ Cities } & \multicolumn{2}{|c|}{2001} & \multicolumn{2}{|c|}{2002} & \multicolumn{2}{|c|}{2003} & \multicolumn{2}{|c|}{2004} & \multicolumn{2}{|c|}{2005} & \multicolumn{2}{|c|}{2006} & \multicolumn{2}{|c|}{2007} & \multicolumn{2}{|c|}{2008} & \multicolumn{2}{|c|}{2009} & \multicolumn{2}{|c|}{2010} & \multicolumn{2}{|c|}{2011} & \multirow{2}{*}{ Total } \\
\hline & PI & MU & PI & $\mathrm{MU}$ & PI & $\mathrm{MU}$ & PI & MU & PI & $\mathrm{MU}$ & PI & MU & PI & MU & PI & MU & PI & $\mathrm{MU}$ & PI & MU & PI & MU & \\
\hline $\begin{array}{c}\text { Duque de } \\
\text { Caxias }\end{array}$ & - & - & - & - & - & - & - & 2 & 2 & 1 & 1 & 2 & 1 & 1 & 2 & - & - & - & - & - & - & 2 & 14 \\
\hline Nova Iguaçu & 1 & 1 & 1 & 1 & 1 & - & 1 & 3 & 3 & - & - & 1 & - & - & 3 & - & 1 & - & 1 & 2 & - & - & 20 \\
\hline $\begin{array}{l}\text { São João de } \\
\text { Meriti }\end{array}$ & - & - & - & - & - & - & - & - & - & 1 & - & - & - & 2 & - & - & - & - & - & - & - & - & 3 \\
\hline Belford Roxo & - & - & - & - & - & - & - & - & - & - & - & - & - & - & - & - & - & - & - & - & - & - & 0 \\
\hline Japeri & - & - & - & - & - & - & - & - & - & - & - & - & - & - & - & - & - & - & - & - & - & - & 0 \\
\hline Queimados & - & - & - & - & - & - & - & - & - & - & - & - & - & - & - & - & - & - & - & - & - & - & 0 \\
\hline Seropédica & - & - & - & - & - & - & - & - & - & - & - & - & - & - & - & - & - & - & - & - & - & - & 0 \\
\hline Itaguaí & - & - & - & - & - & - & - & - & - & - & - & - & - & - & - & - & - & - & - & - & - & - & 0 \\
\hline Mesquita & - & - & - & - & - & - & - & - & - & - & - & - & - & - & - & - & - & - & - & - & - & - & 0 \\
\hline Nilópolis & - & - & - & - & - & - & - & - & - & - & - & - & - & - & - & - & - & - & - & - & - & - & 0 \\
\hline Paracambi & - & - & - & - & - & - & - & - & - & - & - & - & - & - & - & - & - & - & - & - & - & - & 0 \\
\hline
\end{tabular}

The evolution of patent records shows an oscillation in the number of patent filings by resident companies over the years, the increase in the number of patents in 2004 and 2005 seen in the survey of companies in the Baixada Fluminense does not reflect the national situation, since in 2009 there was an increase in the deposit of patents in the country which was not reflected in the companies of the region studied. The resident enterprises from the Baixada Fluminense region concentrate 49\% of their innovative force in the IP type, and the other 51\% of the UM type. In the years 2005 and 2008 there were increases in the registration of patents of invention, having in other years remained low and constant.

The results presented in Table 3 show the ranking of patent applications by industries studied, sorted by the number of patents by type and total patents in the period. The company with the highest registration of patents in the region is the Cia.Canetas Compactor with 11 patents, concentrating $29.7 \%$ of the total requests. Moreover, the proportion of the IP type of patents held was noteworthy.

Table 3 - Ranking of companies by number of patents registered.

\begin{tabular}{c|c|c}
\hline CNPJ & Industries & TOTAL \\
\hline $30.742 .555 / 0001-70$ & COMPANHIA DE CANETAS COMPACTOR (BR/RJ) & 11 \\
\hline $30.092 .431 / 0001-96$ & CONDOR S/A INDUSTRIA QUIMICA & 4 \\
\hline $33.303 .231 / 0001-23$ & INDUSTRIA DE PLASTICO E VIDROBRAÇO LTDA & 4 \\
\hline $33.255 .787 / 0001-91$ & IBF INDUSTRIA BRASILEIRA DE FILMES S/A & 3 \\
\hline $07.305 .785 / 0001-50$ & PNAPLES INDUSTRIA E COMERCIO DE PLASTICO LTDA & 3 \\
\hline $01.144 .673 / 0001-88$ & ENGETECH COMERCIO E INDUSTRIA DE PLASTICOS LTDA & 2 \\
\hline $30.770 .184 / 0001-30$ & INDÚSTRIAS GRANFINO S/A (BR/RJ) & 2 \\
\hline $29.950 .060 / 0001-57$ & NORTEC QUIMICA S.A. & 2 \\
\hline $36.456 .945 / 0001-60$ & BKNAV INDUSTRIA E COMERCIO LTDA & 1 \\
\hline $31.069 .347 / 0001-14$ & IMS COMERCIAL E INDUSTRIAL LTDA & 1 \\
\hline $00.990 .949 / 0001-86$ & INJETAMP INDUSTRIA COMERCIO E SERVICOS LTDA & 1 \\
\hline $08.035 .564 / 0001-71$ & MULTPLAST INDUSTRIA E COMERCIO DE ARTEFATOS PLASTICOS LTDA & 1 \\
\hline $30.153 .506 / 0005-25$ & NIELY DO BRASIL INDUSTRIAL LTDA & 1 \\
\hline $27.952 .712 / 0001-67$ & VALEQ VALVULAS E EQUIPAMENTOS INDUSTRIAIS LTDA & 1 \\
\hline
\end{tabular}


Aligned with Macedo (2010), regarding protection gains in territory competitiveness, the strong participation of companies in the plastic manufacturing sector is evident in the number of patent applications. Companies in the plastics sector have a higher percentage of companies in the region and this is reflected in the number of patent applications. The number of patent applications of product companies was driven by the company manufacturing pens, pencils and other office supplies; holding 11 patents.

\section{FINAL CONSIDERATIONS}

This article seeks to conduct an analysis of the region in terms of innovation and patents, recognizing that the statistics have limitations as a regional indicator of innovation activities. The subject of the patent refers directly to the chronic difficulty of scientific research institutions and Brazilian private sector, which directly affects innovation, and hence the competitiveness of the geographic national economy. It is necessary for the research to incorporate more indicators that portray the nature and the innovation effort of the regions.

The analysis of patents filed with the INPI enabled the qualification of the resident companies registering patents in the region of the Baixada Fluminense, Rio de Janeiro. Quantitatively, the predominance of non-resident patents tends to be significant (this is a feature common to other countries with immature innovation systems). Qualitatively, the work indicted that in resident companies there was a predominance of smaller tech patents (utility models). It shows the prevalence of the practical use of new forms, involving an inventive act and susceptible to industrial application.

Compared to the socio-economic importance of the Baixada Fluminense region, the industries generating patents, the object of this study, presented a lower middle record. Only $9 \%$ of the industries studied are holders of patents in the period analyzed and 91\% of the industries have no registered patent. This result can be considered a reflection of the national panorama, the registration of patents by industries that reside in the country is quantitatively negligible to that of non-resident industries. The study shows a concentration of patents in two districts and municipalities with no records of patents registered to companies in them. As for distribution by sector, there is a concentration of patents in three sectors and in the other the distribution of patents by industry occurs on a regular basis.

Regarding the type of registered patents, both invention patents and the utility model are registered by companies with no quantitative disparity. There was no patent registration certificate in some locations. The emergence of this technology gap points to companies and cities with a low innovation capacity. From the current analysis, it appears that there is a low use of patents by the industries of the region studied. This can be conditioned by factors that are independent of the country condition of development. One is the lengthy and bureaucratic process that lasts an average of eight years for the various steps to be met. In addition, the high costs involved in these steps and during the validity of the patent-letter are also assessed against the returns arising from the new technology.

Due to the factors mentioned above, patents may be set aside as a protection method used by industry in relation to other means, such as the trade secret, however, patents provide companies with both the security of the bases of innovation and the possibility of negotiations and market achievements. The low average of patents and the high percentage of companies with no patent show that government incentives are not aligned with an approach recognized as Evolutionary Economic Geography.

The idea that innovation is a key factor for economic growth and business performance is overwhelming. The income from the relationship between innovation and profitability is related to competition policy and issues regarding human capital and the provision of expertise, and are of most interest to managers and investors. Thus, the result of this study shows a certain weakness of the industries in the region due to the lack of patenting and innovation generation. 
Among the benefits perceived in the study of investment in patents are: innovation as the main barrier to competitors; the increase of the company's intangible value; and the appreciation of the product by the customer, in addition to the natural benefits of exclusive exploration of a given technology and the protection of R\&D investments for a long-term return.

Given the considerable contribution of the indicators in the construction of a national policy, it is important to recognize the need for a national basic patent that is easier to use and able to integrate current indicators with others, thus contributing to the dissemination and mapping of available technologies. New studies are recommended to expand the universe studied herein, covering companies in the state and making possible comparisons of resident companies in the state and those in the study region. An analysis of the internal politics in industries to confront the empirical results obtained in this study and raise the main factors that cause industries to have different performances in the treatment of the ownership of intellectual property would also enrich the understanding of this topic.

\section{BIBLIOGRAPHICAL REFERENCE}

ABRAHAM, B.P.; MOITRA, D.S. Innovation assessment trought patent analysis. Technovation, v.21, n.4, p.245-252, 2000.

ANDREASSI, T. Gestão da inovação tecnológica. São Paulo: Thomson, 71 p. -- (Coleção Debates em Administração), 2007.

ARCHIBUGI, D.; PIANTA, M. Measuring technological change through patents and innovation surveys. Technovation, v.16, n.9, p.451-468, 1996.

AUDRETSCH, D.B., ALDRIDGE, T.T. Scientist commercialization as conduit of knowledge spillovers. The Annals of Regional Science, Ann Reg Sci, v.43, p.897-905, 2009.

BARBIERI, J.C.; ÁLVARES, A.C.T. Inovações nas organizações empresariais. In: BARBIERI, J.C. (Org.). Organizações inovadoras: estudos e casos brasileiros. 2. ed. Rio de Janeiro: FGV., 2004.

BARBOSA, D.B. Propriedade intelectual: da convenção de Paris ao patamar do novo milênio. Política de Propriedade Intelectual, Negociação, Cooperação e Comercialização de Tecnologia em Universidades e Instituições de Pesquisa (workshop). Rio de Janeiro: Rede de Tecnologia do Rio de Janeiro, 2010.

BESSANT, J.; TIDD, J. Inovação e empreendedorismo. S/L: bookman, 2009.

BRASIL. Lei $\mathbf{n}^{0}$ 9.279 de 1996. Disponível em <http://www.planalto.gov.br/ccivil_03/leis/19279.htm>. Acesso em 24 nov. 2013.

CANONGIA, C.; PEREIRA, M.N.F.; ANTUNES, A. Gestão da informação e monitoramento tecnológico: o mercado dos futuros genéricos. Perspectivas em Ciência da Informação, v.7, n.2, p.155-166, 2002.

CERETTA, S.B.N., FROEMMING, L.M.S. City marketing: dimensões importantes para uma cidade de bem viver. Revista Produção e Desenvolvimento, v.1, n.3, p.67-79, 2015.

COSTA, F.J.P., RODRIGUES, M.G. Energia, meio ambiente e inovação tecnológica. Revista Produção e Desenvolvimento, v.1, n.2, p.15-26, 2015.

CUNHA, M.B.; CAVALCANTI, C. R. O. Dicionário de Biblioteconomia e Arquivologia. Brasília: Briquet de Lemos, 451 p., 2008.

FORNARI, V. C. B., GOMES, R., CORREA, A.L. Indicadores de inovação: um exame das atividades inovativas na indústria internacional de alimentos processados. Revista Brasileira de Inovação, Campinas (SP), v.14, n.1, p.135-162, 2015.

FREEMAN, C. The economics of hope. London, Pinter, 1992.

GODIN, B. Measuring Output: When Economics Drives Science an Technology Measurements. Observatoire des Sciences et des Technologies. Working Paper n. ${ }^{\circ}$ 14, 2002.

GRILICHES, Z. Patent Statistics as Economic Indicators: A Survey. Journal of economic Literature, v.28, n.4, p.1661-1707, 1990. 
INPI. O que é patente? - Portal INPI. Disponível em: <http://www.inpi.gov.br/menu-esquerdo/patente/ pasta_oquee>. Acesso em: 20 dez. 2013.

LAZZARI, F., BAMPI, R.E., SPERANDIO, G.M. Os esforços de inovação e sua relação com alguns indicadores de desempenho do negócio. Revista Produção Online, Florianópolis, SC, v.14, n. 1, p.58-83, 2014. MACEDO M. F. G.; BARBOSA, A. L. F. Patentes, pesquisa \& desenvolvimento: um manual de propriedade intelectual. Rio de Janeiro: Fiocruz, 2000.

MARICATO, J.M.; NORONHA, D.P. FUJINO, Asa. Análise bibliométrica da produção tecnológica em biodiesel: contribuições para uma política em CT\&I. Perspect. ciênc. inf., Belo Horizonte, v.15, n.2, Aug. 2010 MCCANN, P. Schools of Thought on Economic Geography, Institutions, and Development. IN: FISCHER, Manfred M. Handbook of regional science. Heidelberg: Springer, 2014.

MELLO, J.A.V.B.; RIBEIRO MELLO, A.J.; ORRICO FILHO, R.D. Centralidad basada en viaje y su reflexión sobre la estrutura monopolicéntica de la Región Metropolitana de Río de Janeiro. Investigaciones Geográficas, [S.1.], n. 89, p. 74, mar. 2016. ISSN 2448-7279.

NONAKA, I.; TAKEUCHI, H. The knowledge creating company. Oxford: Oxford University Press., 1997. RAEDER, S. Geography and technological innovation. Mercator, Fortaleza, v.15, n.2, p.77-90, apr./jun., 2016.

RÉGIBEAU, P.; ROCKETT, K. Are more important patents approved more slowly and should they be? Economics Discussion Papers 556, University of Essex, Department of Economics, 2003.

RODRIGUES, R.S. GONÇALVES, E. HIERARQUIA URBANA E DISTRIBUIÇÃO ESPACIAL DE INVENÇÕES NO BRASIL. Enaber, 2015.

SABINO, L.S. Caracterização da proteção às patentes como estímulo ao desenvolvimento econômico. Dissertação (Mestrado em Direito)-Universidade Católica de Brasília, Brasília, 2007.

SÁENZ, T., GARCIA, E.C. Ciência, Inovação e Gestão Tecnológica. Brasília, 136p., 2002.

SALINAS, R.K. Introdução ao direito autoral. In: CRIBARI, Isabela (Org.). Produção cultural e propriedade intelectual. Recife: Fundação Joaquim Nabuco, Editora Massangana, 2007.

SANTOS, J.G.C., GÓIS, A.D., DIAS, S.M., REBOUÇAS, P., SILVA FILHO, J.C.L. Efeitos da inovação no desempenho de firmas brasileiras: rentabilidade, lucro, geração de valor ou percepção do mercado?. Revista de Administração da UNIMEP. v.14, n.3, Setembro/Dezembro- 2016

SCHUMPETER, Joseph A. Teoria do desenvolvimento econômico: uma investigação sobre lucros, capital, crédito, juro e o ciclo econômico. Maria Sílvia Possas (Trad.). São Paulo: Abril Cultural, 1982.

SERRANO, B. P.; GOBBO J.R. Redes de inovação: mapeamento de inventores de patentes em uma empresa do setor de cosméticos. GEPROS. Gestão da Produção, Operações e Sistemas, Bauru, v.9, n.1, p.101-113, 2014.

SOUSA, D. C. et al. Análise do impacto das patentes no índice global de inovação com aplicação de lógica paraconsistente anotada. Exacta - EP, São Paulo, v.12, n.2, 2014.

SUZIGAN, W.; FURTADO, J.; GARCIA, R.; SAMPAIO, S.E.K. Inovação e conhecimento: indicadores regionalizados e aplicação a São Paulo. Rev. econ. contemp. [online], v.10, n.2, p.323-356, 2006.

TEIXEIRA, F. Tudo o que você queria saber sobre patentes, mas tinha vergonha de perguntar: e também sobre marcas, pepeline, invenção, design, pirataria, falsificação, royalties e muito mais. Rio de Janeiro: Multimais, 1997.

WANDSCHEER, C.B. Patentes e Conhecimento Tradicional. Curitiba: Juruá, 2004. 